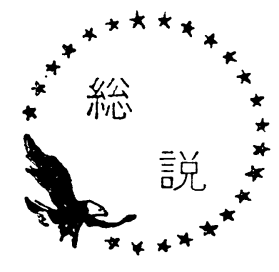

日本における石炭地下ガス化の開発
東京大学 外 尾 善 次 郎

\section{I 、日本における石炭地下ガス化の意義と可能性}

日本で石炭の地下ガス化を開発して炀こうとする動 きが積極的になつたのは，3 年程前通産省石炭局が中 心となつて「石炭地下ガス化調査委員会」を発足させ てからである。すでにこの委員会も 3 年目を迎えた。 日本で現場試験する場合の候被地の選定も終り, ま灷 段階的な試験内容の検討も行なつてきた。しかし, 日 本にお汀る石炭地下ガス化現場試験実施のみ上沶乙 は，今のところ決して明るいとはいえない。金の出ど ころがないからでめる。石炭の地下ガス化は「新しい エネルギー資源の開発」であるといら見地から，われ われは国家の資金的援助を願つていた。しかし具体的 な企業の強力なバックアップがなければ，国の金はで てこない。

現在の石炭業界之は, 直接的には石炭の地下ガス化 は結びつか子い。たとえ関係があるとしても, 現在の 石炭企業の客観情勢では, 石炭の地下ガス化一関心を 払らら程の余裕があろらはずもない。ガス利用の立場 にある電力やガス関係者へのアッピールもまだ不足し ている。

また端的にいつて，つぎのような素朴な疑問が誰の 頭にも浮かんでくるに違いない。

（1）ソ連で成功しているというのは本当だろうか。

（2）ヨーロッパや米国でそれ程熱を入れていないの

に日本で開発するとしても成功するだろらか。

（3）もし日本で地下ガス化を実施するとした場合,

どのようにすればよいのだろらか。

さて，一昨年と昨年の 2 回にわたりモスコウでソ連 石炭地下ガス化公団総裁のスカーファ氏に合つて, 直 接話を聞く機会があった。この時の報告はすでに他誌 ${ }^{122)}$ に書いたし，またソ連の地下ガス化については最近 朝日新聞にも報告された。ソ連では成功しているので ある。

ただ 5 億 $\mathrm{t}$ 以上の総出炭量に比べれば，現在約 25 億 $\mathrm{m}^{3} /$ 年といら地下ガス化ガスの生産量はきわ问下少な いといわざるをえない。しかし，坑内学衝在なくしそ
れでも石炭資源を利用してりくという彼らの目標の第 一段階注完全に成现したよて上い。スカーフア氏に よれば，この目標への努力怯今後も続汀られるこ上注 当然であり, 将来シベリヤや極桌方面でも大規模な不 炭地下ガス化ステーションの閏設分訢画されている。 ソ連に招ける不炭地下ガス化は，すでに独立採算でき

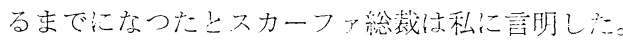

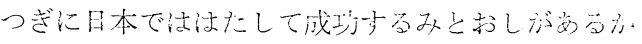
どうか。そう簡㧘にしかも短期間で性企業化へもつて ゆけるとは考えられないが，段階的な試験之その結果 の累積によつて，必らず企業化へもつてゆけると私梳 考えている。イギリスで現場試験安実施しながら，天 の後進展をみないではないか上いら意見もまる。しか し,イギリスあるいは、ーロッパのエネルギー事情は， 日本とは相当大きな相違がある。ぼう大な天然ガス資 源が発見されたヨーロッパ(イギリス例外ではない) では, 天然ガス開発を緊急の目標上するのは当然で方 ろう。

日本での石笑地下ガス化開発には, 特別な条件が具 つていることを私は指摘したい。そして以下述べる 「坑内法による石炭の地下ガス化」では, ソ連の坑外法 に比較して，これは日本の特殊性としていえることで あるが，大きな利点が考えら机る。すなわち

(1) 坑内採掘が経済性の点で成り立たないために, 多くの炭鉱が閉山されてきたし, 今後も数多くの 炭鉱が閉山されるに違いない。しかし閉山炭鉱は 埋蔵炭量が涸渴したということではなく，まだ莫 大な石炭資源が賦存している場合が多い。こ机を そのまま永久に放棄するといらことはない。

(2) 閉山炭鉱を利用し, ソ䢚式の坑外からの地下ガ ス化ではなく, 玾内法による地下ガス化技術の開 発を目ざせば，技術的にも容易でめり，かつ資金 的にも有利になる。すなわち, 現場試験投資が坑 外法の時のように多く在要しない。

(3) ソ連における地下ガス化ガスの生産コストの中 で約 $1 / 3$ 注ボーリング費である。廃山炭鉱を利用し 
坑内既存の坑道を利用すれば，ボーリング費はほ とんど不要になる。坑外からの指向性ボーリング は非常に高度の技術を必要とする。坑内法にすれ ばその技術の開発が不要になる。

（4）地下水の存在流外法では大きな問題となり, 排水費も生産コストに大きく影響するが，坑内法 ではそれ程問題にならない。

（5）炭層や地山からのガス抜き技術は，日本では完 全に成功している。これと同じように坑内ガス化 ガスは坑外へ誘導できる。

石炭は, 日本に与えられた唯一の豊富なエネルギー 資源であることは現在でも変わりはない。石炭採掘が 経済的に成立しなくなつても，この石炭を地下でガス 化し，これを利用しょうとすることは，新しいエネル
ギー資源の開発として国家的にもきわめて意義あるも のといわなければならない。

スカーファ総裁は，「日本は非常に多量のLPGを輸 入しているではないか。日本で石炭のガス化を実施す ればLPGよりも安くできるはずだ。石炭地下ガス化ガ スをLPGと混用して使用すれ标，大きな国家的利益が あげられるはずであるが」と昨年彼は強調した。つぎ にまずソ連に抢ける地下ガス化の現状について，その 概略を述べるとにする。

\section{II. ソ連における石崖地下ガス化の現状}

\section{1. 地下ガス化ガス生産量の推移}

1940年から1965年までの, ソ連における石炭地下ガ ス化ガス生産量の推移は表 1 , 図 1 のとおりとなつて いる ${ }^{92}$ 。

\section{表-1 ソ連における石炭地下ガス化ガス生産量の推移}

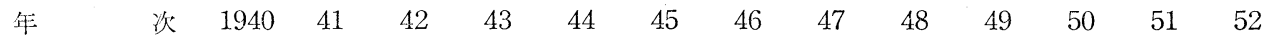

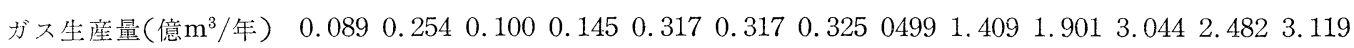

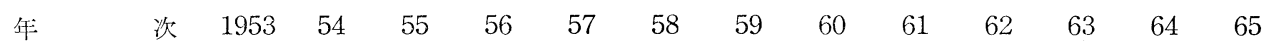
ガス生産量(億 $\mathrm{m}^{3}$ /年) 3.985 4.414 5.418 5.825 6.261 7.6308 .288 6.64 8.33 9.341 $13.922 \quad 18.40$ 25.00

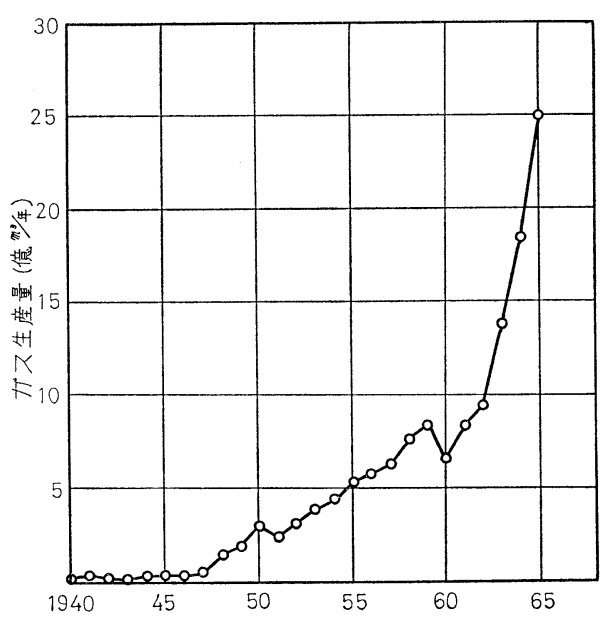

図 1 ソ連における石炭地下ガス化ガス 生産量の推移

図1からわかるよらに，1965年までの過去数年の生 産量の増加は特に著しい。

2. 石炭地下ガス化ステーション

さて，現在ソ連には，リシチャンスク，ユージュノ アビンスク，シャッスク，アングレン，カメンスクの 5 つの地下ガス化ステーションが稼㗢している。ポト モスコウの地下ガス化ステーションは，多くの現場研 究実績を残して1963年に終了した。以下各ステーショ
ンの概要学述べよう。

(1) リシチャンスク地下ガス化ステーション

ドンバスのドニエック市北東 $160 \mathrm{~km}$ のところにあ る。0.5 1.0mの12枚の厚層があり $30 \sim 40^{\circ}$ の傾斜を もつているが, その露頭部のところをガス化している。 頁岩と石灰岩が夾炭層で炭質の分析結果流 2 のお りである。発熱量 4,500kcal，揮発分 35\%で湧水が多 いといわれている。

1934年はじめて試験が実施され，第二次大戦で破壊 されたが1948年に復興し，炭層に沿つた長孔ボーリン グ技術の開発，2本のボアホール間を圧気や高圧水， あるいは電気でリンキングする方法の研究や，さらに 指向性ボーリング技術の開発研究が行なわれている。

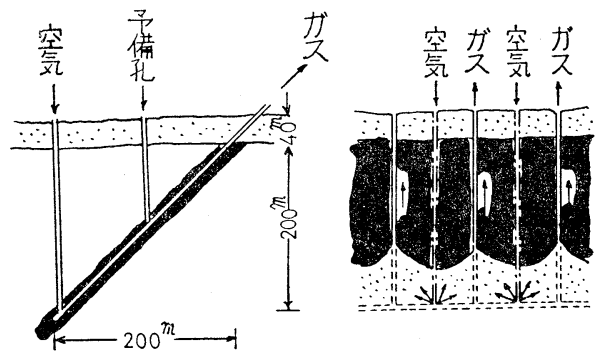

図 2 リシチャンスク・地下ガス化 ステーションのガス化方式 
ガス化方式としては，図2に示すように，岁深さま で炭層に沿つてボアホールをさく孔し(間隔約 $35 \mathrm{~m}$ ), この傾斜ボアホールの中間に垂直ボアホールをあけ る。この両者間を炭層内でリンキングし，垂直ボアホ 一ルを入気孔，傾斜ボアホールを排気孔としてガス化 を行なう。燃焼は炭層の傾斜にそつて上方へ移動して ゆく。1962 年に 2 億 900 万 $\mathrm{m}^{3}$ の生産量をあげている。 1963年，2億2360万 $\mathrm{m}^{3}$ である。

（2）コージュノ・アビンスク地下ガス化ステーション

酉部シベリや，クズバスのキーゼロフスク市外にあ る。炭たけ1〜9m（平均 $2.5 \mathrm{~m}$ ) の23枚の炭層をもち, 傾斜 $60 \sim 70^{\circ}$, 夾炭層は粘士質頁岩之軟い砂岩で, 歴青 炭の発熱量注 $6,960 \mathrm{kcal}$ である。分析結果は表 2 に示 している。

1955年からガス化を開始している。ガス化方法はリ シチャンスクの場合と似ているが，沿層ボーリングの 外に下盤からのボーリングを実施して(図 3 ), ガス化 に伴う地層沈下による孔ゔまりを防止している。稼行 炭たけが厚いからである。計画生産量は1962年，8000 万 $\mathrm{m}^{3} ， 1963$ 年 10 億 $\mathrm{m}^{3} ， 1964$ 年 15 億 $\mathrm{m}^{3} ， 1965$ 年 20 億 $\mathrm{m}^{3}$ で岗つたが，1963年実績で2.88億的 ${ }^{3}$ なつている。

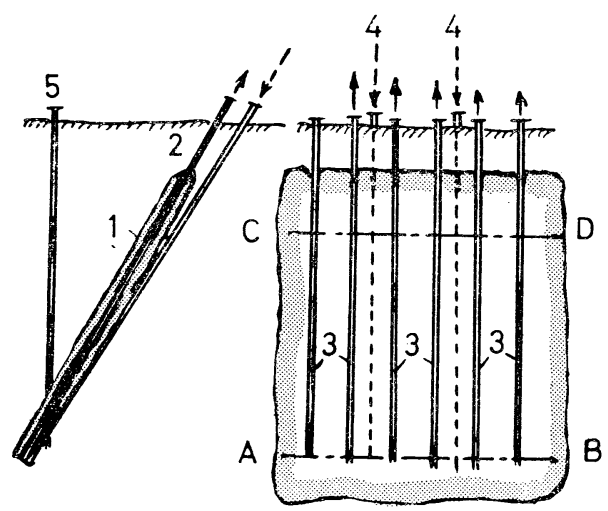

1-涔層 2-ガス排出ボアホール3-炭層傾斜方 向にさく孔された送風ボアホール4-送風用の 開発ボアホール5-連結ガス化キャナルABを作 るための重㨁ボアホール $\mathrm{CD}$-炭層ガス化上限

\section{図 3 ユージュノ・アビンスク地下ガス化} ステーションNo.2地下ガス発生炉

（3）シャッスク地下ガス化ステーション

ポドモスコウ炭田にあり，ポドモスコウ地下ガス化 ステーションの終了に代わるべく建設されたもので, 1956 年に建設され 1957年 3,000 万 $\mathrm{m}^{3}$ のガスを生産し た。空気リンキングカ式でガス化し, 主要設踊として は8気圧, 容量 $6,000 \mathrm{~m}^{3} / \mathrm{h}$ のコンプレッサー5台, 2.2
気圧, 容量 $55,000 \mathrm{~m}^{3} / \mathrm{h}$ のコンブレッサー 3 台をもち, はじめ $12,000 \mathrm{~kW}$ の発電機2台をガスタービン駆動で

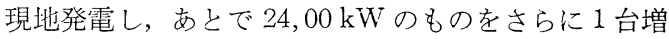
設の計画である。

（4）アングレン地下ガス化ステーション

ウズベック共和国の首都タシュケントの東南 $120 \mathrm{~km}$ のアングレン炭田にある。炭たけ1.6 21.1m(平均9. $2 \mathrm{~m}$ ), ガス化稼行深さ $110 \sim 195 \mathrm{~m}$ (平均 $150 \mathrm{~m}$ ), 傾斜 5 $15^{\circ}$, 炭質は褐炭で発熱量 $3650 \mathrm{kcal}$ で，分析結果は表 2 のさおりである。

直接天盤は $40 \mathrm{~m} の$ 厚さの炭質頁岩であるがその上部 が20 30mのカオリン層のた対，炭質頁岩注一部ガス 化されるが漏ガスは少ない。被覆層には含水層を含ん でいる。

1958年にガス化を開始したが，1963年の生産ガス量 8億8000万 $\mathrm{m}^{3}$ で，ソ連地下ガス化ステーションの中で 規模は最大である。ここの炭層は厚いためガス化によ つて上層部の沈下が生ずる。そのた好アホールは水

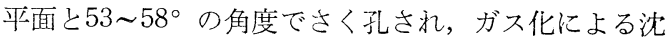
下の影響をボアホールが受けないようにしてある。圧 気，電気，水力破砕などのリンキング方式をとつてい

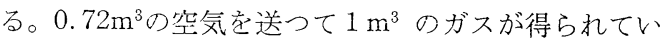
る。設備としては $55,000^{3} / \mathrm{h}$ のコンプレッサーを有し ている。

以上の外にカメンスク地下ガス化ステーションがあ り，現在終了したポドモスコウステーションのデータ もめるので，とめて表示すると表 2 の晾りとなる。 ガス生産量さガス生産原価の推移をまとめると表 3 のと款である。

表 3 からガス生産量の増加に伴ら生産コスト低下の 実績を知ることができるが，その生産コストの内訳を みてみると表4 のようになつている。ボーリング費用 が相当大きいウエイトを占めていることがわかる。

3 . 生産量増加と生産コストの低下

ガス生産量の増加に伴つて, 原価が低下してくるこ とは当然であるが，ユージュノ・アビンスクではつぎ のような計画があり，ガス生産原価は大幅に低下する ことになつている。

第 1 次計画一1964 1965年に年間ガス生産量を 8億 $\mathrm{m}^{3}$ とする。

第 2 次計画一1970年までにガス生産量を年間 28 億 $\mathrm{m}^{3}$ とする。

この湯合の生産原価はつぎのように安くなる。 $\left(1000 \mathrm{~m}^{3}\right.$ 当りのルーブル) 
表-2 ソ連における石炭地下ガス化ステーションの総括

\begin{tabular}{|c|c|c|c|c|c|c|c|}
\hline \multicolumn{2}{|c|}{ ステーション名 } & ポドモスコウ & リシチャンスク & $\begin{array}{c}\text { ユージュノ } \\
\text { アビンスク }\end{array}$ & & シャッスク & カメンスク \\
\hline 炭 & $\begin{array}{c}\text { 田 } \\
\text { 量 }(\text { 万 } \mathrm{t} \text { ) }\end{array}$ & $\begin{array}{c}\text { ポドモスコウ } \\
680\end{array}$ & ド ネ ッ & $\begin{array}{c}\text { クズネッ } \\
19,000\end{array}$ & $\begin{array}{c}\text { アングレン } \\
\text { 4,500 }\end{array}$ & $\begin{array}{c}\text { ポドモスコウ } \\
2,700\end{array}$ & ネ \\
\hline 炭䄱 & 曾の厚さ (m) & $\begin{array}{l}0.3 \sim 5.7 \\
(\text { 平均 } 2.0)\end{array}$ & $\begin{array}{c}0.4 \sim 1.2 \\
(0.8)\end{array}$ & $\begin{array}{r}1 \sim 9 \\
(2.5)\end{array}$ & $\begin{array}{l}\text { 1. } 6 \sim 21.1 \\
(9.2)\end{array}$ & $(1.9)$ & $(1.0)$ \\
\hline 傾 & 斜(度) & 0 & 45 & $60 \sim 70$ & $5 \sim 15$ & 0 & $50 \sim 52$ \\
\hline 深 & 度 (m) & $34 \sim 60$ & $200 \sim 350$ & & $110 \sim 195$ & 40 & 500以内 \\
\hline 孷 & 質 & 褐 & $\begin{array}{l}\text { 瀝青炭 } \\
\text { 純炭 }\end{array}$ & 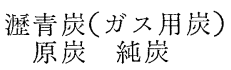 & $\begin{array}{l}\text { ）褐 } \\
\text { 㟶崖 }\end{array}$ & 褐 & 半無煙炭 \\
\hline & $(\%)$ & 32,00 & $59.00 \quad 80.0$ & 75.2084 .40 & $43.30 \quad 76.2$ & & 67.50 \\
\hline & $(\%)$ & 2.35 & $3.00 \quad 4.0$ & $4.37 \quad 4.90$ & $2.30 \quad 4.0$ & & 3.10 \\
\hline & $(\%)$ & 13.03 & 7.00 & $7.14 \quad 8.00$ & 10.40 & & 1.00 \\
\hline & $(\%)$ & 0.77 & 3.00 & $2.12 \quad 2.35$ & $0.50\} 1.78$ & & 1.10 \\
\hline & (\%) & 1.60 & 2.00 & $0.31 \quad 0.35$ & 1.50 & & 1.70 \\
\hline 灭 & 分 $(\%)$ & 25.10 & 15.00 & $4.86-$ & 11.00 & 37.00 & 13.00 \\
\hline 水 & 分 $(\%)$ & 25.15 & 11.00 & 6.0 & 31.00 & $25 \sim 44$ & 12.00 \\
\hline & 発 分 $(\%)$ & $22 \sim 24$ & 35 & 34.5 & 25.3 & & 8.8 \\
\hline 発 & 熱 量(kcal) & 2,720 & 4.500 & $6,960 \quad 7,800$ & 3,650 & 2,600 & 6,300 \\
\hline 上 & s. & 粘 土 層 & 頁岩·石灰岩 & $\begin{array}{l}\text { 㗀質頁岩 } \\
\text { ジ砂岩 }\end{array}$ & $\begin{array}{l}\text { 岸啠頁岩 } \\
\text { 少 }\end{array}$ & 砂層・粘土層 & $\begin{array}{l}\text { 砂質 - 粘土 } \\
\text { 岩 }\end{array}$ \\
\hline 下 & 盤 & $\begin{array}{l}\text { 粘 良層 } \\
\text { 石 }\end{array}$ & 頁岩・石灰岩 & 同 上 & $\begin{array}{l}\text { 粘 土層 } \\
\text { シルト岩 }\end{array}$ & 粘 土 層 & 砂質頁岩 \\
\hline & $\begin{array}{l}\text { 又発熱 量 } \\
\left(\mathrm{kcal} / \mathrm{m}^{3}\right)\end{array}$ & $700 \sim 800$ & 820 & $900 \sim 1,100$ & 800 & 900 & 900 \\
\hline リン & ンキング法 圧 & $\begin{array}{l}\text { 王気 } 3.5 \sim 4.5 \text { 気 } \\
\text { 電気水力破确 }\end{array}$ & 王) 水力破硝 & 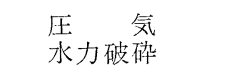 & $\begin{array}{l}\text { 圧気, 電気 } \\
\text { 水力破砕 }\end{array}$ & 気 & 水力破砕 \\
\hline
\end{tabular}

\section{表-3 各ステーションのガス生産量と原価}

\begin{tabular}{|c|c|c|c|c|c|c|c|c|}
\hline \multirow[b]{2}{*}{ 年 } & \multicolumn{2}{|c|}{ ユージュノ・アビンスク } & \multicolumn{2}{|c|}{ リシチャンスク } & \multicolumn{2}{|c|}{ ポドモスコウ } & \multicolumn{2}{|c|}{ アングレン } \\
\hline & $\begin{array}{l}\text { 扮不生産量 } \\
\left(100 \text { 万 } \mathrm{m}^{3}\right)\end{array}$ & $\begin{array}{l}\text { ガ ス 原 } \\
\text { ル 価 } \\
\text { ル }\end{array}$ & $\begin{array}{l}\text { ガ } \text { 否 } \\
\text { 生産量 }\end{array}$ & ガス原価 & $\begin{array}{l}\text { 出不量 } \\
\text { 生産量 }\end{array}$ & ガス原価 & $\begin{array}{l}\text { 架否 } \\
\text { 生産量 }\end{array}$ & ガス原価 \\
\hline 1959 & 104.7 & 5.95 & 136.9 & 7.83 & 430.0 & 3.84 & - & - \\
\hline 60 & 148.0 & 4.44 & 116.0 & 6.43 & 437.0 & 3.62 & - & - \\
\hline 61 & 230.0 & 3.33 & 198.0 & 3.81 & 361.5 & 3.45 & 77.0 & 2.76 \\
\hline 62 & 255.6 & 2.40 & 209.0 & 3.12 & 304.3 & 4.43 & 494.1 & 2.82 \\
\hline 63 & 288.3 & 2.19 & 223.6 & 3.60 & - & 3.96 & 880.3 & 2.30 \\
\hline
\end{tabular}

表-4 $1962 \sim 1963$ 年の生産原価内訳

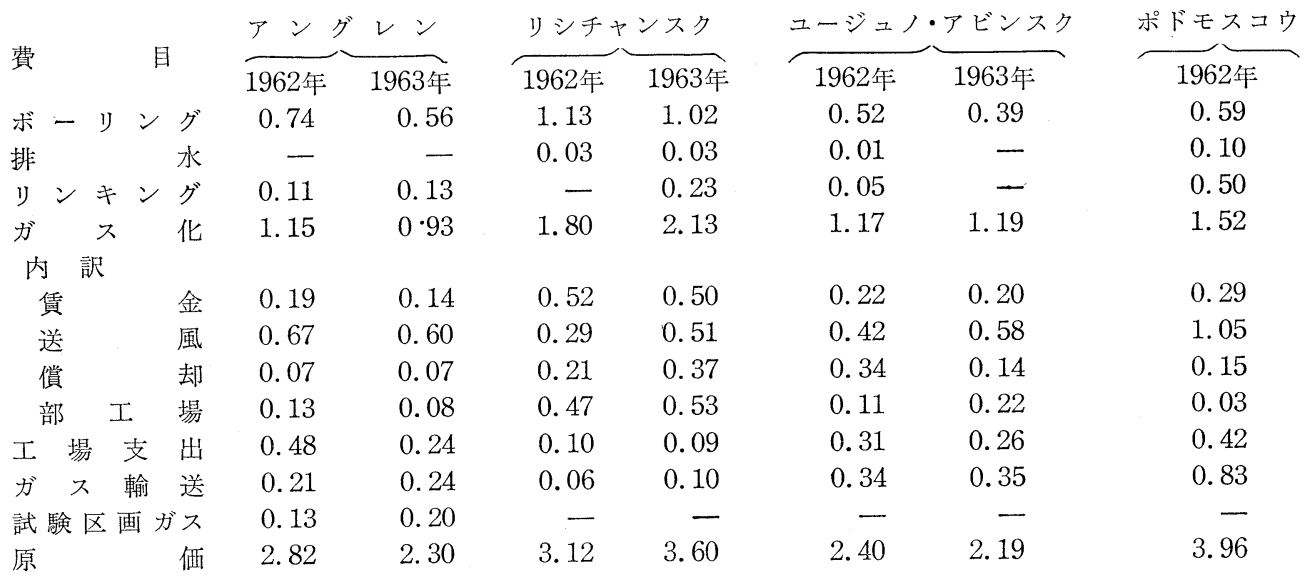

（注）単位はすべて $1000 \mathrm{~m}^{3}$ 当たりのルーブル 
第 1 次咶画 第 2 次計画

\begin{tabular}{|c|c|c|}
\hline 賃金，給料 & 0.112 & 0.06 \\
\hline 償＼cjkstart却 & 0.230 & 0.12 \\
\hline 材 料 費 & 0.014 & 0.01 \\
\hline 部工場支出 & 0.09 & 0.06 \\
\hline 工場支出 & 0.29 & 0.06 \\
\hline 地下ガス化発生炉準備費 & 0.132 & 0.10 \\
\hline 送風吹込費 & 0.366 & 0.21 \\
\hline ガス輸送費 & 0.348 & 0.20 \\
\hline & 1.582 & 0.82 \\
\hline
\end{tabular}

第 2 次計画が達成されると, $1,000 \mathrm{~m}^{3}$ 当りのガス生 産コストは0.82ルーブルとなる。

\section{4. ガス利用}

ソ連のガス化ステーションでの発生ガスはつぎのよ うな方面で利用されている。

$$
\begin{aligned}
& \text { リシチャンスク………9 } \mathrm{km} \text { 離れた発電所へ送られ } \\
& \text { ジャッスク……………発電所 } 2 \text { つ（各発電所出力 } \\
& \text { は, } 12,000 \mathrm{~kW})
\end{aligned}
$$

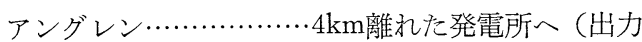

$$
\begin{aligned}
& 10 \text { 万 } \mathrm{kW} \text { ) }
\end{aligned}
$$

これは1963年のデータであるからその後多少の変更 はあるかも知れない。

\section{III. 日本における石炭の地下ガス化(坑内法)}

日本で石炭地下ガス化を実施する場合，坑内法を採 用すれば前述したような長所があることを述べた。ソ

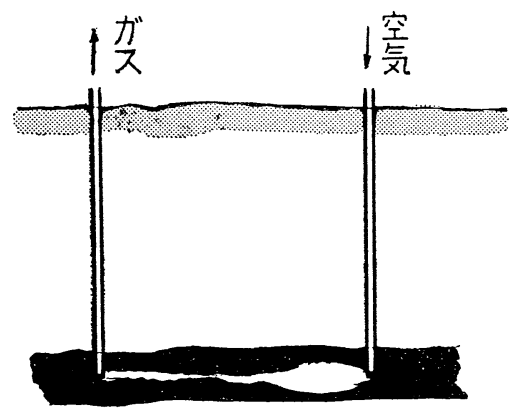

図 4 地表からのガス化方式
連における石炭地下ガス化の第一の目標が「㙂内学働 の廃止」ということにあるとしても，わが国では一足 飛びにそこまでゆけるはずはないし，糜山炭鎮の利用 といら点からも坑内方式が望ましい。地表からの地下 ガス化(ソ連式)では，2本のボアホールを2う〜 30m間 隔で炭層までおろし，てれ各種リンキング方式で崖 層内にキヤナルを作つて（あるいは，もう1本の指间 性ボアホールで, この両方のボアホールを連結させ), 1 方のボアホール先端で着火させ, 空気または酸素䈏 化空気を送つてガス化を続行させるわけである。(図4) 廃山炭鈗を利用した坑内法では，すでに既存の坑道が あるわけであるから,坑道で炭層のところまでゆける。 あと法外法と同じように，一方の坑道 (送風坑道) から他の坑道(ガス坑道) 一炭層内へボアホールをあけ

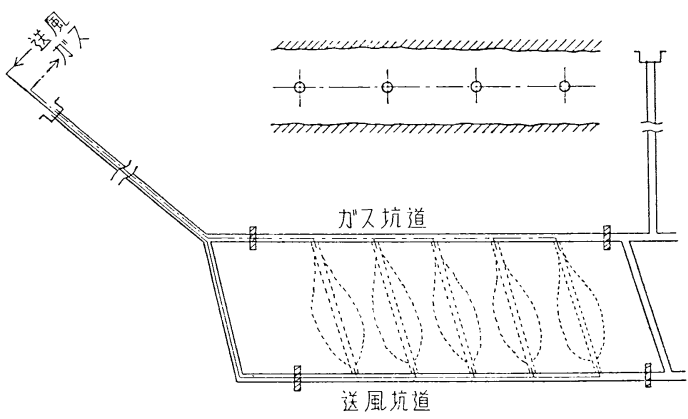

図 5 坑内地下ガス化方式

（図 5）一端で着火させ空気を吹き込んでガス化し， 発生したガスはボアホール他端からガス坑道をとおつ てパイプで坑外へ誘導する4)。図 5 に示すように $1 つ$ のガス化区画を围みその間に多くのボアホールを炭層 内にあけ，これをガス化キヤナルとしてガス化してゆ こうとするこの方式では，つぎの諸点が明らかにされ なければならない。
(a)炭層内ボアホールの径
(b)ボアホール間隔
(c)ボアホールの長さ
(d) 1 本のボアホールへ吹込む空気の量

これらの諸要素を決定し, 坑内方式の場合のデイメ ンションを決定するために, 大学で行なつてきた理論 解析および実験研究結果の概略を述べよう。

まず,ボアホールの径は,大きくとればさく孔するこ と自体が容易ではなくなる。したがつて現在の技術と 機械で今すぐにでも問題なくできるものが好ましい。

径 $60 \mathrm{~mm}$ 程度のものであれば問題はない。つぎにこ の $60 \mathrm{~mm}$ のボアホール内部1端で着火した場合，吹込 
み送風量に従つてボアホール壁面の温度がぞらなるか は理論解析で求めることができ, 実験でも検討されて いる。

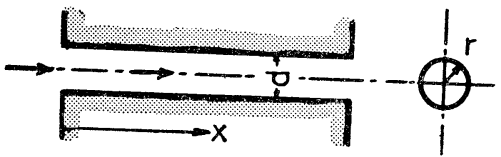

図 6 ボアホール断面

いま図 6 のように座標系をとり1端から送風した場 合，ボアホールキャナル壁面の温度はつぎのようにな $る^{5)}$ 。

$$
\begin{gathered}
\theta=\theta_{0}+\frac{\left(T_{m}-T_{0}\right) \xi}{\left(1+\frac{\alpha}{h}\right)(\zeta-\xi)}\left\{e^{-\xi S x}-e^{-\zeta S x}\right\} \\
+\frac{G C_{p}}{h S^{\prime}} \cdot \frac{\left(T_{m}-T_{0}\right) \xi}{\left(1+\frac{\alpha}{h}\right)(\zeta-\xi)}\left\{\zeta S e^{-\zeta S x}-\xi S e^{-\xi S x}\right\}
\end{gathered}
$$

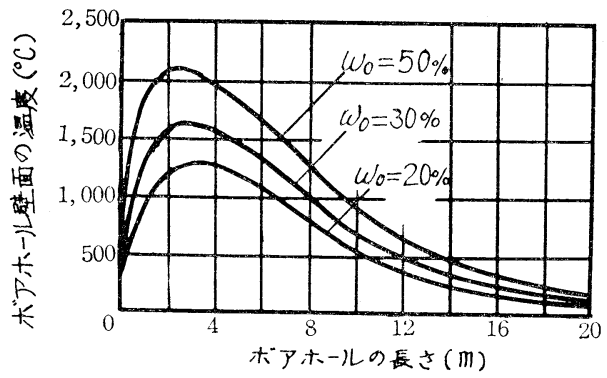

図 7 ボアホール壁面の温度分布

ボアホール径 $60 \mathrm{~mm}$ として送風量 $7 \mathrm{~m}^{3} / \mathrm{h}$ のときの 壁面温度分布を図 7 に示している。3 本の曲線は送風 中の酸素ガス含有量 $\omega_{0}$ が $20 \% ， 30 \% ， 50 \%$ のきで, $\omega_{0}$ の值が増加すれば当然壁面の温度は増加する。 式で

\section{$\theta:$ ボアホール壁面の温度}

$\theta_{0}:$ 炭層の着火前温度

$T_{m}$ : ボアホールに入つてくるガス(吹込多空気)の 理論上の最高温度

$T_{0}:$ ボアホール入口でのガス(吹込空気)の温度 $\xi=\frac{N_{u}}{R_{e}}, N_{u}:$ Nusselt数, $R_{e}:$ Reynolds数

$h:$ ボアホール壁面(反応面)とガス間の伝熱係数 $S=4 / d, d:$ ボアホール直径

$\zeta=\frac{\alpha}{\left(1+\frac{\alpha}{h}\right) G C_{p}}$

$G$ : 質量速度

$C_{p}:$ ガス定压比熱 $\alpha$ ：ボアホール壁面と炭層内部との間の総括伝熱係 数

いま, $A=\frac{\left(T_{m}-T_{0}\right) \xi}{\left(1+\frac{\alpha}{h}\right)(\zeta-\xi)} \quad B=A \times \frac{G C_{p}}{h S}$

とおくと，

ボアホール壁面に㧍ける燃焼火源の移動速度 $V$ は 次式のようになる。

$$
\begin{aligned}
V= & \frac{-F+D \theta_{0}+e^{-\xi S x}(A-B \xi S)\left(D+C \xi S-\lambda \xi^{2} S^{2}\right)}{E\left\{\xi S(C \xi S-A) e^{-\xi S x}+\right.} \\
& \frac{-e^{-\zeta S x}(A-B \zeta S)\left(D+C \zeta S-\lambda \zeta^{2} S^{2}\right)}{+\zeta S(A-B \zeta S) e^{-\zeta S x\}}} \cdots(2)
\end{aligned}
$$

ただし

$F=Q v \frac{d \omega}{d x}$

$Q:$ 酸素ガスの有効発熱量

$\omega:$ 酸素ガス濃度（吹込み送風中の）

$v:$ 酸素ガスの吹込み速度

$D:$ 乱流搪散係数

$E=\rho C_{p_{0}}\left(\rho:\right.$ 石炭比重, $C_{p_{0}}$ : 石炭の比熱 $)$

$C=v C_{p}\left(v:\right.$ 酸素ガス流速, $C_{p}:$ 酸素ガス比熱 $)$

$\lambda:$ 石炭の熱伝導率

（2）式から送風量と，燃焼火源の移動速度 $V$ との関 係を示したのが図 8 である。これによると空気のみ吹 込む場合には， $60 \mathrm{~mm}$ 径ボアホールに対しては，大体 $8 \mathrm{~m}^{3} / \mathrm{h}$ で，これ以上では，かえつてVの值が減少する

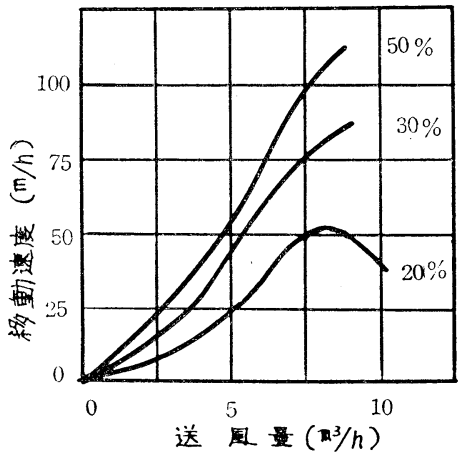

図 8 送風量と燃焼火源の移動速度との関係

ことがわかる。ガス化の場合は，もちろんVの值が大 きい程好ましいわけであるから，空気吹込みの時は 8 $\mathrm{m}^{3} / \mathrm{h}$ でガス化を開始すればよいということになる。し かし，ボアホールの径は燃焼が進むにつれて次第に拡 大してゆくはずである。ガス化初期ではボアホールの 壁面最高温度は $1,300^{\circ} \mathrm{C}$ 程度であるが，同じ送風量で あればボアホールの燃燒拡大につれて, その最高温度 は次第に低下してくる。その状態を図 9 亿示している。 


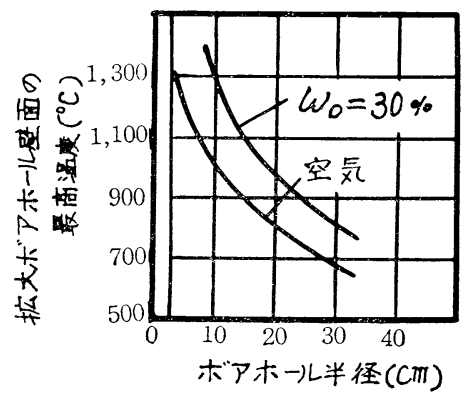

図 9 ボアホール燃焼拡大に伴なう壁面 温度の低下

最高温度が $1,000^{\circ} \mathrm{C}$ 以下に低下したのでは，努まし いガスは得られない。また炭層の燃え桩がりも昰くな る。したがつて，炭層内部への然え拡がりをよくする 方法を構じなければならない。図10に示している4゙の は, ボアホール壁面の最高温度を, ボアホールが燃焼 拡大しても低下させないために必要とする, 送風量の 増加の状態である。

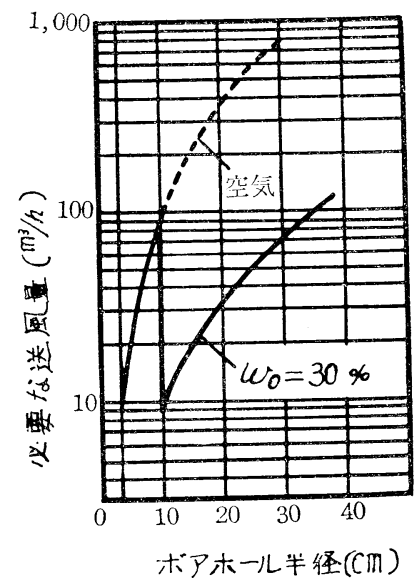

図10 ボアホールの燃焼拡大に応じた必要送風量

これによると，ボアホールが次第に拡大して半径 10 $\mathrm{cm}$ になっ場合には，100 $\mathrm{m}^{3} / \mathrm{h}$ の空気を吹き込まなけ ればならないことがわかる。それ以上に拡大すれば， $200 \mathrm{~m}^{3} / \mathrm{h}$ 近い空気定吹込まなければ，以前と同じよう に然焼带が拡がつてはゆかない。実際問題としてそれ 程多量の送風を行なうのは問題が多いため，この場合 多少の酸素を添加してやるとよい。罒10に示している ように, 30\%の酸素気化空気に切替えると, 半径 $40 \mathrm{~cm}$ 直径 $80 \mathrm{~cm}$ 程度にボアホールが拡大しても，100 $\mathrm{m}^{3} / \mathrm{h}$ 程度の吹込みでよい。

実際にはボアホールの然焼拉大は不均一で，またボ
アホール内に海焼で生じた灰が残るた肉，ボアホー ル面積の拉大も時間的には相当変動する（薄層の斨は 熱による天盤崩落もあり，一たん大きくなつたボアホ 一ルがまた小さくなることも生ブる）

ボアホールの長さは，然焼火源のボアホール方向へ の移動速度と, ボアホールさく孔時の技術的問題の両 面から決めなければならない。さく孔技術の点からあ まり長くては好ましくない。上下盤から等しい点すな わち炭層の中心部にさく孔を開始しても，50６0mさ く孔する間に孔曲り在生ずる。図 5 で送風坑道からさ く孔し, ガス坑道へ貫通させる場含, 送風坑道では炭 層の中心部にさく孔しても，ガス坑道で上盤や岕るい は下盤へボアホールが出てくるようなことがあつては 困る。したがつて，さし当つては50m以内が好ましい ことになる。ソ連における研究結果によると, ボアホ 一ルの長さと発生ガスの発熱量, ガス成分とは相互関 係があり，大体25～30m程度が好ましいことを，ポド モスコウの現物試験で明らかにしている。しかし，こ の場合收炭層にボアホールをあけたのではなく，2本 のボアホール（地表からの）間は圧気リンキングでガ ス化キャナルを作つているので，われわれが日本で実 施しようとする場合上は多少翼なつているかも知れな

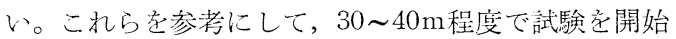
すべきだと思う。

結局，日本で地下ガス化試験を尖施する場合は，つ ぎのようなディメンションで開始すればよい。

(1) ボアホールの直径は60 65 $\mathrm{mm}$ 程度

(2)ボアホールの長さ $40 \mathrm{~m}$ 程度

(3)ボアホール間隔 $2 \mathrm{~m}$ 程度

(4) 1 本のボアホールへは着火してしばらくの間は $8 \mathrm{~m}^{3} / \mathrm{h}$ の送風で, ボアホールが燃燒拡大するに つれて次第に増加し $100 \mathrm{~m}^{3} / \mathrm{h}$ 程度にする。それ 以後は $30 \%$ の酸素離化空気に切替え, 送風量を $10 \mathrm{~m}^{3} / \mathrm{h}$ 程度へ減らし, 時間の経過につれて次 第に $100 \mathrm{~m}^{3} / \mathrm{h}$ まで増加する。

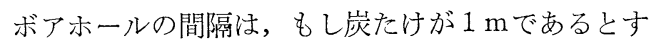
ると, ボアホールが次第に拡大して半径 $50 \mathrm{~cm}$ になれ ば上下盤に到達することになる。上盤が砂岩の場合は 漏ガスが多く好ましくないが，頁岩の場合でも，1,000 ${ }^{\circ} \mathrm{C}$ 以上に加熱されて崩落するよらになる。ボアホール 間隔は炭たけとの関係で決めるべきで， $1.5 \mathrm{~m}$ 程度の 日本の炭層では, 大体 $2 \mathrm{~m}$ 程度にとつておけばよい。

なお送風量を次第に増加してゆく場合, 目安となる のは発生したガスの成分と発熱量の変化で少る。扡大 したボアホールの径に対して送風量が少なすぎると, 
発熱量の低下をきたすわけであるから, 発生ガスの連 続分析によつて, 送風量はコントロールすることがで きる。

以上，きわめて簡単に日本で地下ガス化する場合の 方法を，大よそのディメンションについて述べた。こ の方法は急傾斜炭層に対しても, 緩傾斜炭層について も適用することができる。この場合，送風坑道はガス 坑道よりも深部に，すなわち現在の採炭方式で入気坑 道と排気坑道との関係にとる。

さて, 女まりに概略的に書きすぎたため, 坑内法に よる石炭の地下ガス化は（坑外法も同じであるが）, すぐにでも完全に成功するかのような印象を与えたか も知れない。しかし，考え方がシンプルなだけに，地 下ガス化の生産性に掠よぼす自然条件その他諸要素の 影響は非常に多い。

\section{IV．石炭地下ガス化におよぼす諸要素の影響}

石炭地下ガス化は，いろいろな要素によつて左右さ れる。

\section{自然条件}

炭質（褐炭加瀝青炭加），石炭灰分，揮発分 炭たけ

炭層中に介在する夾みの数と厚さ

上下盤とくに上盤の性状

炭層の含有水分量および地下水

技術的条件

吹込み送風の内容(空気のみか酸素富化空気か)

送風圧, 送風量

リンキング方式
ガス化キヤナルの長さ

この外，その炭層のキレツ性の大小や，炭層の透気 性などの影響もらけ，尗た坑外法の場合法くのボア ホールをあけるわけであるから，ボーリング技術上の いろいろな閴题も生じてくる。以上の諸要素の中か らその主なものについて述べる。

\section{1. 炭たけと夾みの影響}

常識的に判断しても，炭たけは厚い方がよいにきま つているが，わが国ではむしろ薄層 (1m前後)を対称 とする場合が多いと思う。ソ連の実績をみてみると,地 質条件が同じところであれば，炭たけが増すにつれて 発生ガスの発熱量も多少は増加し，1本のボアホール 当りの発生ガス量も増加しているが，ガス化炭量の比 率は減少している。すおちロスが増している(表 5 )。 夾みがあればとらぜんガス化燃焼の扡がりは悪くな り好ましくないことは明らかであるが，ポドモスコウ の垁績データ（表6）をみても，夾みが愿くなるとガ ス化炭量が非常に減少している。大体炭たけの30\%を こす夾みを介在しているよらな炭層は好ましくないと いわれている。

\section{2 . 送風内容とガス成分}

他の条件が同じである場合には，生成ガスの質には 送風成分が大きな影響を与完る。吹込み送風は，一般 に空気のみの場合が多く，目的によつては酸素富化空 気あるいは水蒸気添加を行なつでる。一般に石炭中 には相当の水分量が含有されていて，これがガス化過 程に参加し $\mathrm{H}_{2}$ 成分が生成ガスの中に出てくるが，非常 に乾燥した炭層の場合は，水蒸気吹込みを行ない生成
表 $\quad 5$

\begin{tabular}{|c|c|c|c|}
\hline 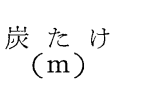 & $\begin{array}{c}\text { ボアホール } \\
\text { 当り崖量 } \\
(t)\end{array}$ & $\begin{array}{l}\text { ガ } \\
(\mathrm{t})\end{array}$ & $\begin{array}{l}\text { 炭 } \\
(\%)\end{array}$ \\
\hline $0.3 \sim 1.1$ & 11,596 & 12,850 & \\
\hline $1.1 \sim 2.0$ & 105,798 & 82,645 & \\
\hline $2.0 \sim 3.0$ & 260,274 & 195, & \\
\hline $3.0 \sim 4.0$ & 120, & 73 , & \\
\hline & 497, & 364,694 & \\
\hline
\end{tabular}

\begin{tabular}{|c|c|c|c|c|}
\hline \multicolumn{2}{|c|}{ 吹込送風量 $\left(1,000 \mathrm{~m}^{3}\right)$} & \multicolumn{2}{|c|}{ 発生ガス量 $\left(1,000 \mathrm{~m}^{3}\right)$} & \multirow{2}{*}{$\begin{array}{c}\text { 平均ガス発熱量 } \\
\left(\mathrm{kcal} / \mathrm{Nm}^{3}\right)\end{array}$} \\
\hline $\begin{array}{l}\text { ボアホール } \\
\text { (1 本当り) }\end{array}$ & $\begin{array}{l}\text { 崖たけ } \\
(1 \mathrm{~m} \text { 当り) }\end{array}$ & $\begin{array}{l}\text { ボアール } \\
(1 \text { 本当り) }\end{array}$ & $\begin{array}{l}\text { 炭たけ } \\
(1 \mathrm{~m} \text { 当り) }\end{array}$ & \\
\hline 780 & 1,227 & 1,512 & 2,280 & 638 \\
\hline 1,637 & 1,091 & 2,015 & 1,352 & 684 \\
\hline 2,322 & 892 & 2,018 & 776 & 714 \\
\hline 1,554 & 617 & 2,228 & 668 & 703 \\
\hline 1,821 & 912 & 2,020 & 1,030 & - \\
\hline
\end{tabular}

\section{表 6}

爽みの厚さ炭たけ(平均) 灰分(平均) ガス発熱量 炭 (m) (m) (\%) $\left(\mathrm{kcal} / \mathrm{Nm}^{3}\right)$ $0 \sim 0.2$

2.32

$0.21 \sim 0.4$

2. 79

$0.41 \sim 0.6$

2.33

$0.61 \sim 0.8$

2.77

$0.81 \sim 1.0$

2.58
755

715

685

726

738
( $\mathrm{t}$ ) 量

10,145 22,086 32,191 46,478 6,711
量 ガス化炭量

( $\mathrm{t}$ )

8,975

19,442 24,520 33,463 4, 217
ガス化率 (\%)

88.5

88.0

76.1

72.0

62.8
算定したボア ホールの数 6 12 20 26 
ガス中の $\mathrm{H}_{2}$ 成分を増加させることもある。たとえば， ユージュノ・アビンスク地下ガス化ステーションの例 ではつぎのようになつている。

空気吹込み $7,000 \mathrm{~m}^{3} / \mathrm{h}$ でガス発熱量 $1,100 \mathrm{kcal} / \mathrm{Nm}^{3}$ のものが発生した時に水蒸気添加を行ない $1,500 \mathrm{kcal} /$ $\mathrm{Nm}^{3}$ に発熱量は増加し，そのときの成分は， $\mathrm{H}_{2} \mathrm{~S}-0.2$, $\mathrm{CO}_{2}-5 \sim 6, \mathrm{CmHn}-0,1, \mathrm{O}_{2}-0.2, \mathrm{CO}-27 \sim 33, \mathrm{H}_{2}-15$ $\sim 20, \mathrm{CH}_{4}-2 \sim 3, \mathrm{~N}_{2}-43 \sim 47(\%)$ となつた。これを
空気吹込みのみにもよ゙し所，つぎのようにガス成分 は変化し，ガス発熱量はも之の1, $100 \mathrm{kcal} / \mathrm{Nm}^{3}$ にもど つたという。

$\mathrm{H}_{2} \mathrm{~S}-0.1, \mathrm{CO}_{2}-4.5, \mathrm{CmHn}-0.1, \mathrm{O}_{2}-0.2, \mathrm{CO}-27$, $\mathrm{H}_{2}-10, \mathrm{CH}_{4}-2, \mathrm{~N}_{2}-56$ (\%)

表 7 に示しているのは各ステーションでの空気吹远 み送風の時のガス成分例である。

\begin{tabular}{|c|c|c|c|c|c|c|c|}
\hline & & 表 & 7 & & & & \\
\hline & & ガ & 又成 & 分（容 & 積 \%) & & \\
\hline ఏ下ガス化ステーーション & $\mathrm{H}_{2} \widetilde{\mathrm{S}}$ & $\mathrm{CO}_{2}$ & $\mathrm{CmHn}$ & $\mathrm{CO}$ & $\mathrm{H}_{2}$ & $\mathrm{CH}_{4}$ & $\mathrm{~N}_{2}$ \\
\hline シチヤンスク & 1.0 & $16 \sim 18$ & 2.0 & $6 \sim 8$ & $12 \sim 15$ & $1.0 \sim 1.5$ & $58 \sim 60$ \\
\hline ポドモスコウ & 1.2 & $17 \sim 18$ & 0.2 & $5 \sim 7$ & $15 \sim 17$ & $1.0 \sim 1.5$ & $56 \sim 59$ \\
\hline ユージュノ・ & - & $7 \sim 9$ & 0.2 & $18 \sim 22$ & $14 \sim 18$ & $2.0 \sim 2.5$ & $56 \sim 58$ \\
\hline 同 No.2 & - & $10 \sim 18$ & 0.2 & $11 \sim 13$ & $12 \sim 15$ & $1.5 \sim 2.0$ & $57 \sim 59$ \\
\hline
\end{tabular}

吹込み送風中に酸素を添加してやると，ガス成分は とうぜん変化し，発熱量の増加をきたす。図11に示し ているのはリシチャンスク地下ガス化ステーション No.24ガス発生炉の例である。

\section{3. 灰分の影響}

炭層灰分は石炭の地下ガス化過程に本質的な影響を およぼすことが明らかにされている。他の条件が同じ であれば灰分が多いほど発生ガスの 発熱量は減少す る。

図12に示しているのは実験データによる褐炭灰分量 とガス発熱量との関係を示している。また表 8 にはポ ドモスコウの例を示している。これによると灰分が 35 \%から $45 \%$ 几増すと，低カロリーガス $780 \mathrm{kcal} / \mathrm{Nm}^{3} の$ もののパーセントが40.6から 61.3 と増加している。 灰分は地下ガス化過程だけでなく, リンキング過程 （透過法の場合）にも影響する。瀝青炭の場合も図 12 と 大体同じ傾向になる。灰分量が40\%以上になればガス 化上好ましくないしいえる。

\section{表 8}

発熱量 石炭ガス化の場合得られたガス量比率(\%) $\begin{array}{rrr}\left(\mathrm{kcal} / \mathrm{Nm}^{3}\right) & \text { 扊分 } 35 \% & \text { 灰分 } 45 \% \\ 980 \sim 880 & 38.8 & 28.2 \\ 880 \sim 780 & 20.6 & 10.5 \\ 780 \text { 以下 } & 40.6 & 61.3\end{array}$

\section{4.上下盤の性状}

夾炭層岩石としては, 日本ではほとんどの場合が, 頁岩か砂岩であるが，ソ連の場合には直接天盤がうす

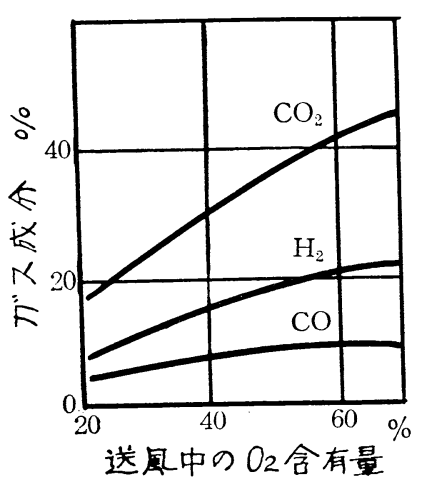

図 11 リシチャンスク地下ガス化ステーショ ンNo.24地下ガス発生炉のデータ

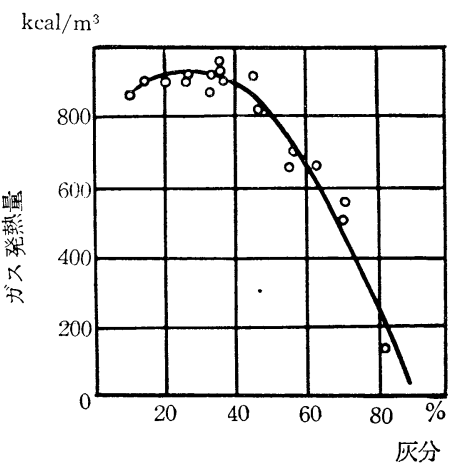

図 12 実験室データによるガス発熱量と 褐炭灰分との関係 
い頁岩でその上が石灰岩という場合もある。岩石は一 般に加熱されるとその強度を著しく減少するといら性 質をもつているが，頁岩と砂岩は多少異なつた性質も 有している。頁岩は加熱とともに次第に灰色から赤み がかつた色に変化し， $1,100 \sim 1,150^{\circ} \mathrm{C}$ 加熱すると非 常に膨張し $1,200^{\circ} \mathrm{C}$ 程度で塑性状態となる。なお $100^{\circ} \mathrm{C}$ 程度ではキレッが発生する。砂岩の場合は加熱ととも に非常にポーラスになりガスを透しやすくなる。

地下ガス化の場合，発生したガスが上下盤をと抒し て漏れては困る。この点から直接天盤が砂岩か砂質頁 岩のものよりも, 頁岩か泥質頁岩などの場合が地下ガ ス化の場合は好ましいといらことになる。ガス化ボア ホール（炭層内）が次第に燃焼拡大して上下盤まで達 する空間ができると，上下盤怔直接的に加熱されるこ とになり，上盤の崩壊や上下盤からのガス漏れなどが 生ずる。夾炭層岩石の熱特性を十分把握することが非 常に大切であること注いうまでもない。

\section{5 . 水分，地下水の影響}

炭層自体多少の水分を含んでいるわけであるが，も し非常に多量の水分がガス化領域に流入してくるよう なことがあれば，燃焼の続行が不可能になるはずであ る。

地表から炭層にボーリングしてガス化する場合, 炭 層上部にもし含水層があれば，ボアホールでその含水 層をつき破ることになり，妿ス化領域炭層に地下水が 流入してくることもありらる。したがつて，その場合 はどらしても水抜き排水ボーリングを実施して，地下 水位が炭層上部にある時は炭層下部まで引き下げる か，含水層があればそこからの水抜き排水を実施しな ければならない。坑内方式ではその坑内を維持するの に排水ポンプの運転が必要であるが，もし廃山炭鉱で ガス化を行ならとすると，すでにその炭鉱には排水ポ ンプ設備はあるわけであるから，それをそのまま利用 すればよい。

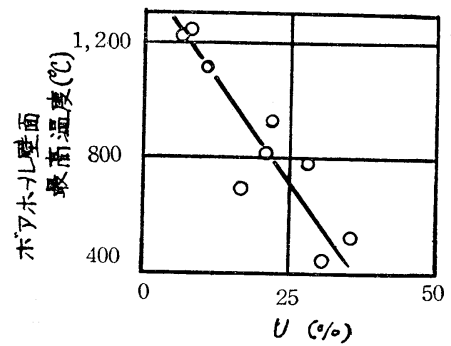

図13＼cjkstart水分量とボアホール壁面最高温度との関係 （ピーチンの実験による）

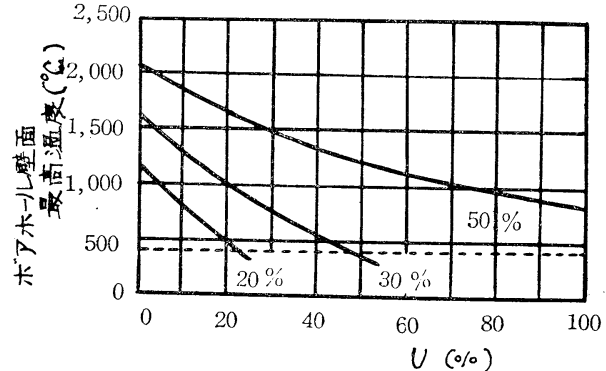

図 14 水分量とボアホール壁面 最高温度との関係

水が存在する場合，燃焼ボアホール壁面の最高温度 が低下寸るわけであるが，これに関してはソ連での実 験結果や，私が行なつた理諭解析結果などがある。図 13に示しているのは，ソ連のピーチン・チェレドコフ が実施した実騟結果, 四14は私の理論解析結果を示し ている。この場合，絶対湿分 $(U)$ とはつぎの上うに定 義した值である。

$$
U=\frac{W}{100-W} \times 100(\%)
$$

Wはある量の石炭重量を 100 とした場合のその石炭 の含有水分重量である。 $W=50$ の場合 $U=100 \%$ とな る。ピーチンらのデータはポドモスコウの褐炭試料に 酸素を送つた場合のもの, 私の解析したものは普通の 瀝青炭の場合で，図中，20\%，30\%，50\%とあるのは 送風中の酸素含有量を示している。

これから，もし空気のみの吹込み送風であれば， $U=5 \%$ 程度で $1,000^{\circ} \mathrm{C}$ を切るようになるから，もし多 少でも地下水が流入してくるようなことがあれば，き わめて好ましくないことになる。30\%の酸素富化空気 であれば $U=20 \%$ 程度で $1,000^{\circ} \mathrm{C}$ をるし，50\%の酸

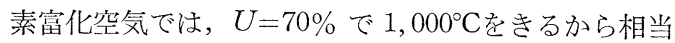
の水分がガス化領域に存在または流入しても，ガス化 が続行できることになる。しかし実際問題として，酸 素富化空気の吹込み送風注経済上その他加ら好ましい とはいえない。しかし完全に湿分のない炭層というも のは存在しないし，また多少の湿分の存在で発生ガス 中に $\mathrm{H}_{2}$ 成分が含まれるわけであるから，この場合は炭 層の自然湿分はかえつて好ましいといえる。

\section{V.むすび}

以上，ソ連に㧍ける石炭地下ガス化の現状について 簡単にのべ，さらに日本で石炭地下ガス化を実施する 場合の 1 つ方式について提案を行ない。日本での地 下ガス化は，段階的開発研究によつて企業化までもつ てゆけることを述べた。この場合，自然条件的にまた 
技術的にいろいろ度要素が地下ガス化に影響孝㧍よぼ す。これらは技術的に解決できるものも文り，まだ不 明のものもある。ソ連の条件では相当明らかにされて いることでも，日本の条件では，かならずしもそれを そのまま全面的に採用できないこともある。

はからずも朝, 九州某炭鉱の坑内事故で数名の犠 牲者がでたことが報ぜられた。炭鉱桨邫はあとをたた ない。坑内採掘を繶けるかぎり災害を完全になくすこ

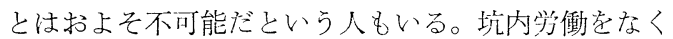
して，しかも石炭資源を有效に利用寸るといらことは われわれの夢であり，また悲願でもある。不岸の地下 ガス化はわれわれに1つの大きな方间孝示しているる らに思う。石炭地下ガス化技術の関発老強く挀えたい と思う。

\section{文献}

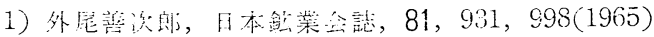

2) 外晊善次郎，動力， 15,88, 18 (1967)

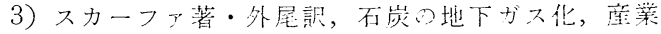
図書, 1964 (Скафа: Подземная Газификацийугля)

4）外尾善次郎，日本錙業会誌，81，920，19(1965)

5) 外尾善次郎, 日本鉱業会誌，80,916, 876 (1964)

6) 外尾善次郎, 日本鉱業会誌，80,918，1041(1964)

7) А. И, Силин-Бекчурин, К.Ф.Богородицкий, В. И. Кононов : Роль подземних вод и других природнюх факторов в лроцессе лодземной Газификаций Угля, Москва 1960

8) АНСССР : Подземная переработка топлив. Москва. 1960

9）石炭地下ガス化調盉霍員食：昭和41年度而崖地下 ガス化に関寸首調查報告基，昭和 42 年 2 月

\title{
Development of Underground Gasification of Coal in Japan
}

\author{
by Zenjiro Hokao
}

(Tokyo University)

SYNOPSIS :- The possible application of underground gasification in Japan and some problems connected with it are now discussed by investigation committee of underground gasification. As well known this underground gasification techniques were mainly developed in Russia and now they produced gasified gas about 2500 million cubic meters per year.

They gasify coal seam by boring from the surface and their first aim is to eliminate underground heavy works in coal mines. Today many coal mines in Japan are scraped for ecconomic reasons. We discuss and propose the underground gasification of coal in scraped mines. Many scraped mines contain sufficient coal seams in which we can carry out trials of gasification. The underground gasification of coal in scraped mine requires some underground works but has also many advantages. We may call this method " underground method" compared with "surface method" in Russia.

Underground method, we are now discuss in committee, has the following advantages.

1. The boring from the surface to coal seam is not necessary and we can use the gallaries and many roads in scraped mine.

2. It is very eassy to make channel of gasification in coal seam. We can bore from the gate road to coal Seam.

3. It is eassy to transport gasified gas to the surface. We can use the pipe lines in gallaries.

We can use many technical data which obtained in Russia and we believe the underground gasification of coal in scraped mines in Japan will be success. 